\title{
Digital Coupon Redemption: Conceptualization, Scale Development and Validation
}

\section{Preeti Nayal}

National Institute of Industrial Engineering (NITIE)

India

\author{
Neeraj Pandey \\ National Institute of Industrial Engineering (NITIE) \\ India \\ npandey@nitie.ac.in
}

\section{Abstract}

The purpose of this study is to develop a reliable and valid scale for measuring digital coupon redemption. The scale development process began with the grounded theory approach for item generation. This was followed by the development of a conceptual framework, item generation, initial reliability analysis, exploratory factor analysis and confirmatory factor analysis (CFA) based on primary data collected from 609 participants. For validating the scale, the CFA was repeated using data from 411 unique participants. Results from two independent surveys supported the proposed scale in terms of construct, convergent and discriminant validity. Survey study resulted in a 45-item digital coupon redemption scale. It also covers digital aspects such as intention to search, attitude toward internet searching, perceived risk, perceived convenience and personal innovativeness which were not covered in earlier promotion scales. This scale would assist marketers to maximize digital coupon redemption during their promotion campaigns. This is the first attempt to provide a comprehensive scale to measure digital coupon redemption in the marketing literature.

Keywords: Scale Development, Digital Coupon, Redemption, Promotion

\section{Introduction}

Global estimates suggest that retail e-commerce sales will account for revenue worth USD 4,878 billion by 2021 (www.statista.com). Not surprisingly, most companies today spend a considerable part of their marketing budget on online promotional tools (Madlberger and Matook, 2017; Pandey and Singh, 2012), such as digital coupons. However, low rates of coupon redemption, which lead to sub-optimal utilization of company resources, have been a concern for most marketers and organizations (Mills and Zamudio, 2018: Pandey and Maheshwari, 2017). Danaher et al. (2015) reported a redemption rate as low as $1.06 \%$ in their longitudinal survey on digital coupons. According to the NCH 2018 report, out of 256.5 billion digital coupons distributed in the United States (US) in 2018, only 1.715 billion coupons were redeemed $(0.7 \%)$.

The extant literature on digital coupons does not offer an empirically tested scale to measure or evaluate digital coupon redemption. Most studies limit themselves to discussing the main variables that influence coupon redemption such as coupon proneness (Chen and $\mathrm{Lu}, 2011$ ), perceived coupon value (Liu et al., 2015), perceived risk (Ha and Im, 2014), and perceived convenience (Danaher et al., 2015). Honea and Dahl (2005) proposed a promotion affect scale (PAS) to measure consumer response to promotion; however, PAS is not tailored to couponbased promotions, and therefore does not consider several coupon-specific factors, including 
coupon proneness and perceived coupon value. Further, consumer behaviour has undergone tremendous changes since the introduction of smartphones, and because PAS was developed in the pre-smartphone era, its applicability to digital coupons is limited.

This study attempts to address the need for a more comprehensive, rigorous, and integrated analysis of coupon redemption by developing a scale for it. This proposed scale can contribute to marketing literature by delineating the construct of "intention to redeem digital coupons" and identifying and validating measures to capture intention to redeem digital coupons. Addressing the call to better understand digital coupon redemption, the study presents a generic scale for coupon redemption that can be used across industries. The standardized scale can also be used by e-marketers to better understand factors that influence digital coupon redemption.

The scale development process is structured according to the procedures suggested by Churchill (1979); Parasuraman et al. (1988); Hinkin (1995) and Tanwar and Prasad (2017). It has three major steps: conceptualization, item generation, and scale refinement and validation (Figure 1). In the following section, we conceptualize the construct of coupon redemption using inputs from grounded theory (GT). This is reinforced by the review of available literature on coupon redemption. Next, we develop a pool of items with the help of both inductive and deductive approaches. Third, the results from our quantitative inquiry are presented to refine and validate the scale for digital coupon redemption. Finally, we discuss how consumer preference for coupons may provide new insights that can enhance the redemption of digital coupons.

The first step in the scale development process is conceptualization of the construct "intention to redeem digital coupons" (Parasuraman et al., 1988; Netemeyer et al., 2003). To accomplish this, we first use an inductive GT approach and then a deductive process based on extant literature. This was followed by finalization of the dependent and independent variables with the inputs from experts. Both inductive and deductive approach were used for item generation of identified key variables. The exploratory and confirmatory analysis were conducted to finalize the coupon redemption intention scale.

\section{Conceptualization of Coupon Redemption}

\subsection{Grounded Theory}

GT is appropriate to apply where the phenomena are quite recent and need more in-depth inquiry (Murphy et al., 2017). Most technology adoption theories do not consider variables from the post-smartphone era; therefore, their relevance and comprehensiveness in explaining digital coupon redemption are questionable. Furthermore, these adoption theories mainly consist of positive variables to explain digital coupon redemption, but one cannot ignore negative variables such as perceived risk to explain digital coupon redemption in the technology era (Im and Ha, 2015). Therefore, in this study, we conceptualize digital coupon redemption and its dimensions using GT. Accordingly, 37 interviews were conducted with 


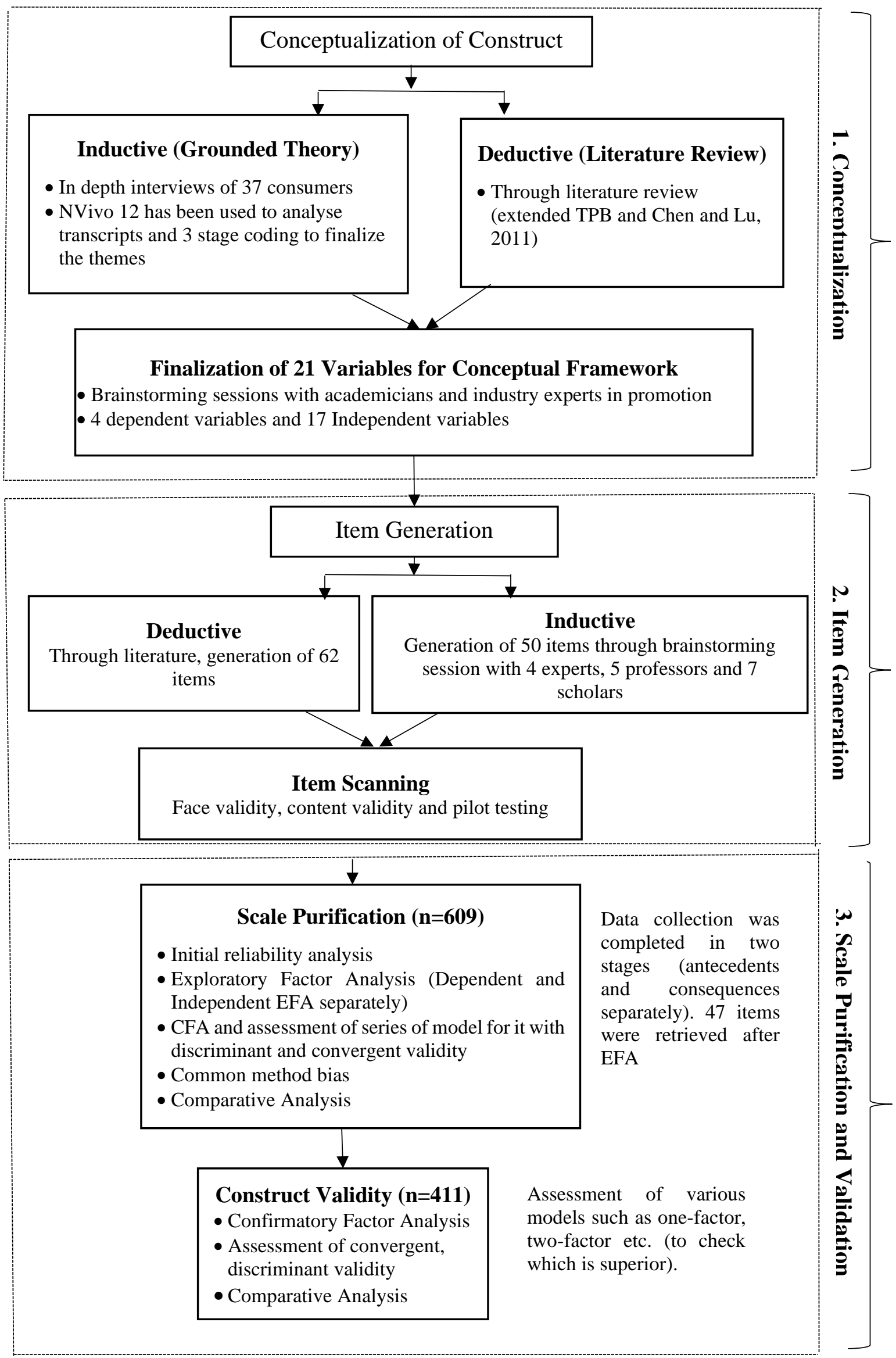

Figure 1: Procedure adopted for Scale Development 
professionals working in diverse sectors, such as information technology (IT), finance, manufacturing, and defence, to ensure data saturation. Each interview lasted for $45 \pm 15$ minutes and was conducted face to face at a mutually convenient location. The consolidated

transcripts of the interviews were analysed using qualitative analysis software (NVivo 12). A three-stage coding process (i.e., open coding, axial coding, and selective coding) was used to finalize the GT model for digital coupon redemption (Corbin and Strauss, 1990). Intention to search was identified as a major theme, followed by coupon proneness and perceived coupon value. The following themes were introduced as antecedents: perceived economic benefits, perceived convenience, perceived usefulness, emotional value, attitude, innovativeness, subjective norms, past experience and perceived enjoyment. Finally, minor themes were added as moderators: face value, customization, expiration date, perceived risk, consumption frequency, and distance.

Excerpts from the interview transcripts are given below:

"I find searching a convenient way to get the latest and most exciting deals" [Intention to search]

"Searching is better than subscription sometimes as you search exactly what you need and do not have fears of spams" [Intention to search]

"Coupons are a good way to save your money and time as sometimes you choose that product to buy for which you have coupon rather than wasting time to decide" [Perceived coupon value]

"I always check the deal for the product which I want to purchase. It makes me feel like a smart shopper." [Coupon proneness]

\subsection{Literature Review}

Factors influencing digital coupon redemption have been studied in the past (Fortin, 200; Kang et al., 2006; Chen and Lu, 2011; Im and Ha, 2013; Danaher et al., 2015). Lichtenstein et al. (1990) explained coupon redemption behaviour with the help of the transaction-utility theory. As per utility theory, coupon redemption is a function of acquisition utility and transaction utility. The theory of reasoned action (TRA), which has been used in two studies from traditional coupon context (Bagozzi et al., 1992; Shimp and Kavas, 1984), posits that a consumer's redemption intention depends on their attitude and subjective norms about coupons. Clark et al. (2013) have used theory of reasoned action (TRA) to explain digital coupon redemption behaviour. Liu et al., (2015) have used unified theory of acceptance and use of technology (UTAUT) theory to explain consumer's redemption intention for digital coupons. The TPB model of digital redemption advances the TRA model by including perceived behaviour control as a third antecedent predicting coupon redemption intention. Fortin (2000) explained coupon redemption behaviour using the theory of planned behaviour (TPB). Ha and Im (2014) studied both positive and negative factors and found that attitude positively influences users' redemption intention while perceived risk negatively influences it. Danaher et al. (2015) tested several drivers of digital coupon redemption such as time of delivery, location, and expiry date but failed to include customization, which is an important variable. Kang et al. (2006) used the same the TPB model but introduced two new variables: attitude toward internet searching and past behaviour with coupons to explain digital coupon redemption. 
Our framework for digital coupon redemption is based on Chen and $\mathrm{Lu}$ (2011) framework which was based on the extended TPB model (Kang et al., 2006). Moreover, Chen and Lu (2011) argued that one cannot ignore coupon proneness as a mediator to explain digital coupon redemption. We have used GT and extant literature to finalize the construct of intention to redeem digital coupons. We consulted four industry experts with an average of ten years' experience in marketing and three scholars of marketing, who had more than 14 years of average academic experience. The conceptual framework, based on the GT and literature review, has been presented in Figure 2.

\section{Variables of the Construct}

The variables of the intention to redeem digital coupons have been categorized as dependent and independent (Figure 2). The dependent variables consist of the intention to redeem digital coupons, the intention to search, coupon proneness, and perceived coupon value. The rest, such as antecedents and moderators, constitute the independent variables.

\subsection{Dependent Variables}

Consumers who access digital coupons exhibit intention to search. Some consumers believe that searching is better because it allows them to find coupons whenever they need without falling prey to unwanted spam (Nayal and Pandey, 2019). Jiménez and Mendoza (2013) showed that the intention to search for coupons as needed has even helped consumers find online reviews about the products/services they wish to purchase. Therefore, it can be expected that intention to search is a key variable to explain digital coupon redemption.

Perceived coupon value was found one of the crucial variables in the context of internet banking (Kumar et al., 2020). Perceived coupon value has been identified as a crucial factor explaining coupon redemption intention (Pura, 2005; Liu et al., 2015; Clark et al., 2013). Similarly, several scholars have argued that consumers' coupon redemption intention cannot be explained without considering coupon proneness (Chen and $\mathrm{Lu}, 2011$; Swaminathan and Bawa, 2005: Clark et al., 2013). Perceived coupon value is more related to acquisition utility that results from the utility of the product and coupon proneness is related to transaction utility that results from the hedonic value of the product (Lichtenstein et al. 1990). Moreover, Souiden et al., (2019) also used utility theory to explain digital coupon redemption behaviour. In the context of online shopping, To et al., (2007) found that hedonic benefits and utilitarian benefits are the main determinants of intention to search or intention to purchase. Therefore, it can be expected that perceived coupon value and coupon proneness are two major key antecedents for intention to search for digital coupons.

\subsection{Independent Variables}

\subsubsection{Antecedents}

Studies have shown that perceived economic benefit positively influences the intention to redeem digital coupons (Raghubir, 2004; Dickinger and Kleijnen, 2008; Souiden et al., 2019), along with perceived convenience (Colwell et al., 2008; Khajehzadeh et al., 2015). Pura, (2005) demonstrated that perceived economic benefit and perceived convenience are key variables to explain perceived value in mobile technology context. Perceived enjoyment refers to the hedonic value associated with redeeming coupons (Wierich and Zielke, 2014; Im and Ha, 2015). Ieva et al., (2019) found that perceived enjoyment is a crucial variable to explain intention to redeem digital coupons. Because digital coupons can be accessed via laptops and 
smartphones, they can be made visually appealing with stickers, emoticons, or sounds. This visualization process makes consumer feel a certain hedonic value while redeeming digital coupons. Ha and Im, (2014) used Rogers's theory to explain adoption of mobile coupons. As per Roger's theory, relative advantage (usefulness) of the given technology is a key determinant to build the adoption intention. Chi and Kilduff, (2011) said that perceived emotional value is a hedonic aspect of perceived value that is aroused by feelings created by product or services. Digital coupon redemption provides shoppers with self-satisfaction and a feeling of being smart (Shimp and Kavas, 1984). Perceived usefulness (Sweeney and Soutar, 2001) and emotional value (Sweeney and Soutar, 2011; Pura, 2005) have been reported as key dimensions of perceived coupon value. Therefore, perceived economic benefit, perceived convenience, perceived enjoyment, perceived usefulness and emotional value are expected to be key dimensions to explain perceived coupon value of digital coupons.

Attitude and subjective norms have also been considered key constructs in technology adoption theories such as TRA and TPB. Subjective norms refer to the social trends and beliefs that influence consumers to adopt a particular behaviour. Chen and Lu (2011) showed that attitude toward digital coupons and toward internet searching, subjective norms, and past behaviour were the key antecedents of coupon proneness. Highly coupon-prone consumers tend to be high on personal innovativeness (Agarwal and Prasad, 1998), and Liu et al. (2015) found that personal innovativeness positively influences one's intention to redeem digital coupons. Some studies (Garretson and Burton, 2003; Clark et al., 2013) have shown that coupon-prone consumers are not only sensitive to price but also seek psychological gains. Therefore, it can be expected that attitude toward digital coupon and internet searching, subjective norms, past behaviour and personal innovativeness are the key dimension for coupon proneness.

\subsubsection{Moderators}

Perceived risk may adversely influence the sharing of personal information online (Featherman et al., 2010; Dang-Pham, Pittayachawan, and Nkhoma, 2015), especially if consumers believe that their information may be used for spamming. Therefore, although a consumer perceives value in digital coupons, s/he may be sceptical to search for it as searching for coupon require personal details sometimes and this study expects perceived risk as a moderator.

Huang et al. (2014) showed that consumption frequency moderates repeat purchase behaviour on online platforms. In fact, when buying online as a group, a consumer's propensity for repeat purchase doing depends on their consumption frequency, which also acts as a moderator (Hsu et al., 2006).

Various studies found that distance to the redemption site negatively influences the chances of redemption (Chiou-Wei and Inman, 2008; Danaher et al., 2015; Beeck and Toporowski, 2017). Travelling long distances to redeem coupons requires spending more time and resources on redemption, which reduces the attractiveness of coupon redemption (Hongjai Rhee and Bell, 2002; Chiou-Wei, 2004). In this study, distance has been considered a moderator. 


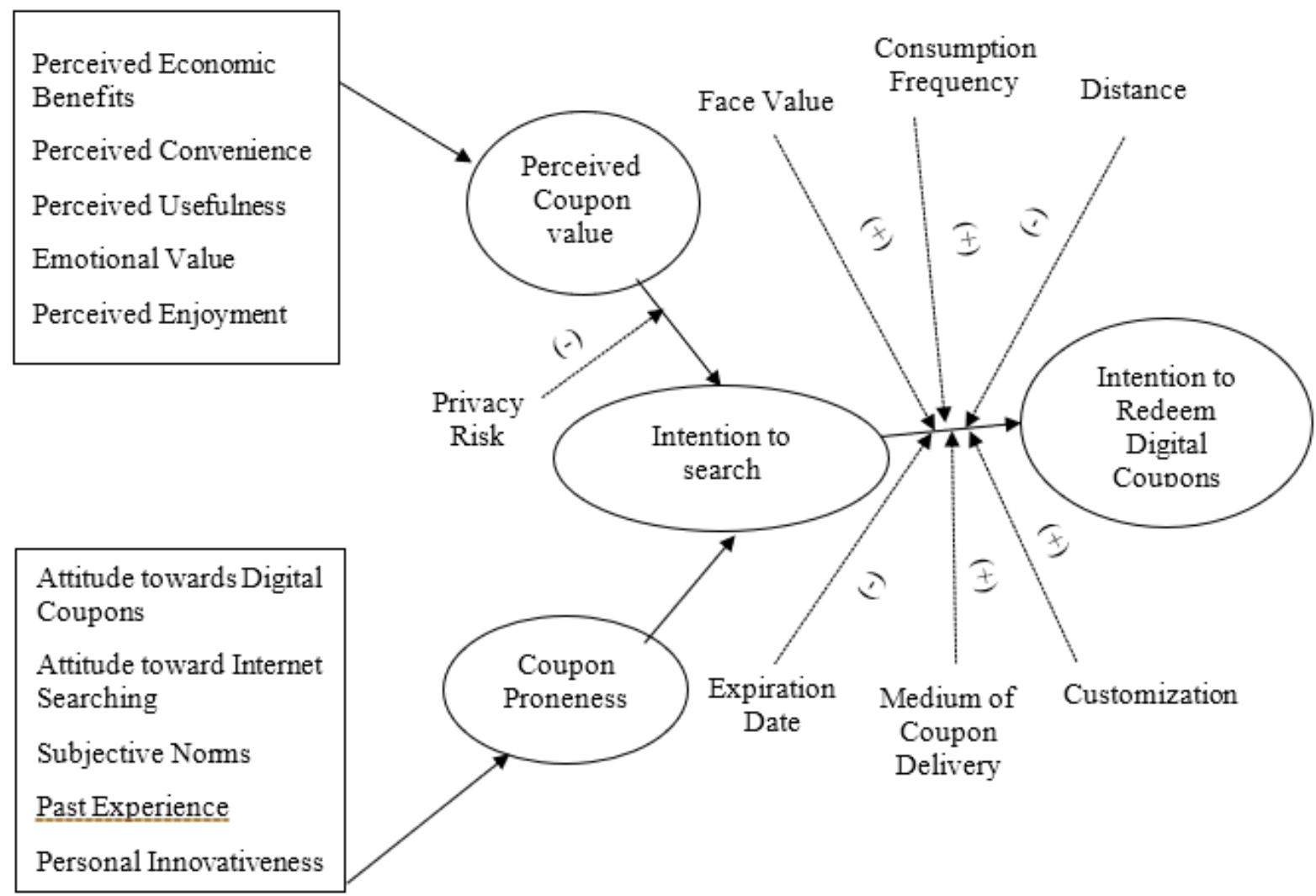

Figure 2: Framework for Intention to Redeem Digital Coupons

After a consumer accesses a coupon - through internet search-its redemption depends on the face value of the coupon. The higher the face value, the higher the chances of digital redemption (Danaher et al., 2015).

Reichhart et al. (2013) noted that the medium of coupon delivery influences consumers' intention to redeem digital coupons. They found a difference between redemption of coupons delivered via e-mail and mobile text messages. Thus, apps, e-mail, and SMS influence coupon redemption intention differently.

Generally, coupon redemption rates are high immediately after the launch date, decline in the middle, and spike again just before the expiration date (Bowman, 1980). Danaher et al. (2015) found that long expiry dates for digital coupons negatively influence coupon redemption intention (Figure 2).

Customization helps companies to deliver the coupon as per the preference of consumers (Danaher et al., 2015). For example, companies track the online browsing history of consumers and send related coupons (Banerjee and Yancey, 2010). It can be also done by sending the coupons to the consumers as per their preferred time of the day.

Once consumer search for the coupons, s/he may register in few coupon websites. S/he may receive coupons. But it is not necessary that redemption happens directly after search, coupon redemption depends on various variables which is considered moderator in current study. These include face value, expiry date, medium of coupon delivery, customization, and distance. 


\section{Item Generation and Refinement}

After conceptualizing the construct, we developed items to measure the intention to redeem digital coupons. Item generation can follow an inductive approach when no theoretical foundation is available in the literature, and the topic needs to be investigated through sample respondents. Alternatively, a deductive approach can also be used when items are well defined in the extant literature (Papadas et al., 2017). This study used both an inductive and a deductive approach to generate the items.

For the inductive approach (brainstorming), we selected four marketing industry experts, seven scholars and five professors from marketing. To be selected, the participants had to have used digital coupons at least once in the last six months. Item generation involved multiple iterations-items were discussed, modified, deleted, and added in preparation for the next step. Finally, 62 items were generated through an inductive approach, and 50 items were generated through a deductive approach. Thus, at the end of this step, we had 112 items to measure digital coupon redemption.

\subsection{Item Finalization Using Expert Opinions}

To determine the content and face validity of the instrument, consisting of 112 items, we conducted an expert review. Two professors, from different universities, who had published papers on scale development in reputed journals were contacted. Additionally, two industry experts with more than 15 years of relevant experience were asked to assess the consistency, appropriateness, and ambiguity of the items. On the basis of the feedback from the experts and professors, the wording of some items was refined, and the final scale was subjected to a pilot test. Each item was evaluated on a 7-point Likert scale, with 1 indicating "strongly disagree" and 7 indicating "strongly agree."

\section{Pilot Testing}

Forty-three participants pilot-tested the scale and shared their feedback on the language, logical sequence, and consistency of the items included. They did not report any difficulty in understanding or answering the questions. No inconsistency, ambiguity, or cultural specifics were observed, and thus, the adequacy of the proposed items was confirmed (Patyal and Koilakuntla, 2015). Because of satisfactory evaluation in the pilot test phase, all the items were retained for final data collection.

\section{Data Collection (1st Stage)}

Data were collected in two stages: on antecedent variables (63 items) in the first stage and on consequence variables (61 items) after a gap of 14 days (second stage). This helped reduce the effect of common method variance, which is associated with a single source and one-time data collection (Podsakoff et al., 2003). For the first stage, we surveyed professionals from various industry sectors; and students studying in University B-schools. The professionals worked in either government or private firms in diverse industries such as banking, human resources, marketing, manufacturing, research, IT, and supply chain. In total, 833 participants were approached, and completed surveys were received from 609 respondents over a period of 10 months. Only respondents who had experience in redeeming digital coupons were invited to participate in the survey. All the survey items were in English as it was well understood by all the participants. 


\subsection{Data analysis}

\subsubsection{Reliability Analysis}

Reliability reflects the consistency of the items on the measurement scale. Cronbach's alpha is a widely used measure of reliability, and an alpha value of 0.60 is considered an acceptable score (Nunnally and Bernstein, 1994). Table 1 shows the results of the reliability analysis of the proposed scale. Two variables with a Cronbach's alpha value less than 0.60 were omitted from the subsequent scale development process. Next, we assessed the corrected item-to-total correlation and discarded items with scores less 0.40 (Nunnally and Bernstein, 1978). Thus, by the end of the reliability analysis, we had retained 84 items: 62 items for independent variables and 22 items for dependent variables.

\subsection{Exploratory Factor Analysis (EFA)}

EFA was conducted separately for the 22 items for dependent variable items and the 62 items for independent variables (Patyal and Koilakuntla, 2015). Before EFA, data appropriateness of the 22 items was assessed through the Kaiser-Meyer-Olkin (KMO) statistic, which was found to be 0.919 . A KMO value above 0.60 is considered satisfactory for EFA (Kaiser and Rice, 1974). The results of Bartlett's test of sphericity were also satisfactory $(p<.01)$, implying that the correlation matrix was "meritorious." Principal component analysis with promax rotation was performed on 22 items as the factors were correlated (Sieger et al., 2016). The EFA yielded a 4factor model, with an eigenvalue greater than 1 for all the factors. All the communalities were above 0.40 . The threshold level for deletion of items was a factor loading of $<0.50$ (Hair et al., 2006). Thus, 9 items were deleted: items with a factor loading less than 0.50 and those that cross-loaded with each other. The EFA analysis identified factors that explained $59 \%$ of the variance.

A second EFA was conducted on 62 items of the independent variables. The KMO for these items was 0.945 , and a principal component analysis with promax rotation was performed on all the 62 items. The EFA resulted in a 9-factor model that explained $61 \%$ of the variance, with an eigenvalue greater than 1 for all the factors. All the communalities were above 0.40 . The threshold level for item deletion was a factor loading $<0.50$ (Hair et al., 2006). As a result, 30 items were deleted. Table 1 shows the factor loading on items in terms of EFA and Cronbach's alpha values.

\subsection{Common Method Bias}

Harman's single factor test was used to examine the potential for common method bias among the studied factors (Podsakoff et al., 2003). High common method variance is indicated if a single factor accounts for more than $50 \%$ of the covariance among the dependent and independent variables (Lindell and Whitney, 2001). In this study, multiple factors were extracted from the principal component analysis, and the first factor accounted for $23 \%$ of the $59 \%$ variance. Thus, we concluded that self-report bias of the respondents is not a concern in this study. 


\begin{tabular}{|c|c|c|c|}
\hline Constructs & Items & $\begin{array}{c}\text { Factor } \\
\text { Loading }\end{array}$ & $\begin{array}{c}\text { Cronbach } \\
\text { Alpha }\end{array}$ \\
\hline \multirow{5}{*}{$\begin{array}{l}\text { Intention to } \\
\text { Redeem Digital } \\
\text { Coupons }\end{array}$} & I will probably redeem the digital coupons & 0.914 & \multirow{5}{*}{0.806} \\
\hline & I am certain to redeem the digital coupons & 0.793 & \\
\hline & I will use a digital coupon if I find something I like & 0.761 & \\
\hline & I like to redeem the digital coupons & 0.732 & \\
\hline & I would consider searching for digital coupons in the near future & 0.503 & \\
\hline \multirow{3}{*}{$\begin{array}{l}\text { Perceived } \\
\text { Coupon Value }\end{array}$} & $\begin{array}{l}\text { When purchasing a product, I always try to maximize the quality } \\
\text { I get for the money I spend }\end{array}$ & 0.892 & \multirow{3}{*}{0.677} \\
\hline & $\begin{array}{l}\text { When I buy products, I like to be sure that I am getting my } \\
\text { money's worthy }\end{array}$ & 0.872 & \\
\hline & Getting digital coupon for combo offers gives me value for money & 0.619 & \\
\hline \multirow{4}{*}{$\begin{array}{l}\text { Coupon } \\
\text { Proneness }\end{array}$} & $\begin{array}{l}\text { Digital Coupons have caused me to buy products I normally } \\
\text { would not buy }\end{array}$ & 0.894 & \multirow{4}{*}{0.746} \\
\hline & $\begin{array}{l}\text { I have favourite brands, but most of the time I buy the brand I } \\
\text { have a coupon for }\end{array}$ & 0.758 & \\
\hline & I am more likely to buy brands for which I have a digital coupon & 0.755 & \\
\hline & $\begin{array}{l}\text { I enjoy using digital coupons, regardless of the amount I save by } \\
\text { doing so }\end{array}$ & 0.5 & \\
\hline \multirow{3}{*}{$\begin{array}{l}\text { Intention to } \\
\text { Search }\end{array}$} & $\begin{array}{l}\text { I search various sites whenever I want to use digital coupons for } \\
\text { a movie }\end{array}$ & 0.867 & \multirow{3}{*}{0.726} \\
\hline & $\begin{array}{l}\text { I find searching coupons on various sites is the best option to get } \\
\text { the coupons }\end{array}$ & 0.747 & \\
\hline & $\begin{array}{l}\text { Searching for the coupons is the good option as you do not need } \\
\text { to register with your personal details }\end{array}$ & 0.736 & \\
\hline \multirow{3}{*}{$\begin{array}{l}\text { Attitude } \\
\text { towards } \\
\text { Coupon }\end{array}$} & It is fun to use digital coupon & 0.964 & \multirow{3}{*}{0.778} \\
\hline & I always look for coupons before buying products & 0.865 & \\
\hline & I react favourably to digital coupons & 0.526 & \\
\hline \multirow{4}{*}{$\begin{array}{l}\text { Subjective } \\
\text { Norms }\end{array}$} & $\begin{array}{l}\text { Using a digital coupon would make me feel accepted by my } \\
\text { friends and family }\end{array}$ & 0.859 & \multirow{4}{*}{0.837} \\
\hline & Society acceptance matters to me for using digital coupons & 0.811 & \\
\hline & I would use digital coupons to get social appraisals & 0.777 & \\
\hline & $\begin{array}{l}\text { Usage of coupons depend on what my acquaintances think about } \\
\text { me when they come to know that I have used coupons to save } \\
\text { money }\end{array}$ & 0.744 & \\
\hline \multirow{4}{*}{$\begin{array}{l}\text { Consumption } \\
\text { Frequency }\end{array}$} & $\begin{array}{l}\text { I will purchase products more often if I receive digital } \\
\text { coupon with combo offer. }\end{array}$ & 0.703 & \multirow{4}{*}{0.734} \\
\hline & $\begin{array}{l}\text { I will purchase products more often if I receive buy one get one } \\
\text { free digital coupon }\end{array}$ & 0.687 & \\
\hline & $\begin{array}{l}\text { I will increase my purchasing frequency if I get substantial } \\
\text { economic benefit from coupons }\end{array}$ & 0.673 & \\
\hline & $\begin{array}{l}\text { I am likely to increase my purchasing frequency if I get Rs.100 off } \\
\text { digital coupon }\end{array}$ & 0.514 & \\
\hline
\end{tabular}




\begin{tabular}{|c|c|c|c|}
\hline Constructs & Items & $\begin{array}{c}\text { Factor } \\
\text { Loading }\end{array}$ & $\begin{array}{c}\text { Cronbach } \\
\text { Alpha }\end{array}$ \\
\hline \multirow{4}{*}{$\begin{array}{l}\text { Distance from } \\
\text { Multiplex }\end{array}$} & I do not mind traveling provided I have digital coupon & 0.815 & \multirow{4}{*}{0.768} \\
\hline & $\begin{array}{l}\text { If medium of travelling is economical, I can go far to redeem the } \\
\text { digital coupons }\end{array}$ & 0.767 & \\
\hline & $\begin{array}{l}\text { If I own a car, distance does not bother me to redeem the digital } \\
\text { coupon }\end{array}$ & 0.712 & \\
\hline & $\begin{array}{l}\text { The ambience of the shopping mall overcomes the pain of } \\
\text { distance travelled to redeem the digital coupon }\end{array}$ & 0.52 & \\
\hline \multirow{4}{*}{$\begin{array}{l}\text { Attitude } \\
\text { towards Internet } \\
\text { Searching }\end{array}$} & $\begin{array}{l}\text { I feel searching the internet gives me an edge in the competitive } \\
\text { world }\end{array}$ & 0.833 & \multirow{4}{*}{0.746} \\
\hline & I feel internet searching adds value to my lifestyle & 0.78 & \\
\hline & $\begin{array}{l}\text { I like searching for information on products online before } \\
\text { deciding to purchase them }\end{array}$ & 0.619 & \\
\hline & $\begin{array}{l}\text { I like to search internet before making any buying decision of any } \\
\text { product }\end{array}$ & 0.612 & \\
\hline \multirow{3}{*}{ Perceived Risk } & In general, I find digital coupons forced & 0.774 & \multirow{3}{*}{0.687} \\
\hline & In general, I find digital coupons disturbing & 0.704 & \\
\hline & In general, I find digital coupons intrusive & 0.658 & \\
\hline \multirow{3}{*}{ Face Value } & $\begin{array}{l}\text { I find coupons with a face value of at least } 10 \% \text { discount worth } \\
\text { using. }\end{array}$ & 0.695 & \multirow{3}{*}{0.676} \\
\hline & $\begin{array}{l}\text { The face value should cover at least the convenience charges } \\
\text { levied on the product }\end{array}$ & 0.514 & \\
\hline & Face value decides the value of digital coupons for me & 0.743 & \\
\hline \multirow{3}{*}{$\begin{array}{l}\text { Personal } \\
\text { Innovativeness }\end{array}$} & I like to experiment with new technologies & 0.776 & \multirow{3}{*}{0.675} \\
\hline & $\begin{array}{l}\text { Among my peers, I am usually the first to try out new } \\
\text { information technologies }\end{array}$ & 0.708 & \\
\hline & $\begin{array}{l}\text { If I heard about a new information technology, I would look for } \\
\text { ways to experiment with it }\end{array}$ & 0.667 & \\
\hline \multirow{4}{*}{$\begin{array}{l}\text { Perceived } \\
\text { Convenience }\end{array}$} & Using digital coupon apps enable me to use coupons at any time & 0.905 & \multirow{4}{*}{0.719} \\
\hline & $\begin{array}{l}\text { Using apps for digital coupon give me convenience to find } \\
\text { needed coupons }\end{array}$ & 0.691 & \\
\hline & Using digital coupons is clear and understandable & 0.574 & \\
\hline & $\begin{array}{l}\text { Using apps for digital coupon enable me to use coupons in any } \\
\text { place }\end{array}$ & 0.565 & \\
\hline
\end{tabular}

Table 1: Factor Loading for Constructs

\subsection{Confirmatory Factor Analysis (CFA)}

CFA was conducted with 609 data points using AMOS version 23.0. The 15-item scale for four dependent factors was validated with the help of CFA. The measurement model was evaluated on the basis of factor loading, standardized residuals, goodness-of-fit indices, and modification indices (Patwardhan et al., 2017). For the dependent factors, modification indices ranged from 4.428 to 14.31 . Two items were omitted because the factor loading was below 0.50 . We deleted the items after ensuring that the deletion does not affect the integrity of the factors (Nahm, et al., 2004). Table 2 presents all the fit indices, which had satisfactory values. Finally, the measurement model contained 13 items (4 dependent factors) that measured the intention to redeem digital coupons. 
Next, we used CFA to validate the 32-item scale covering 9 independent factors. Modification indices ranged between 4.2 and 26.43. No items were deleted as the factor loading of all the items was above 0.50 . The fit indices also showed satisfactory values. Finally, we compared the two proposed models - the 4-factor model for dependent variables and the 9-factor model for independent variables - with a series of other models. Table 3 shows that the 4 -factor solution is the best-fit model for dependent variables, with the lowest $\chi 2 / \mathrm{df}$ and RMSEA(root mean square error of approximation) and the highest CFI (comparative fit index) and GFI(goodness fit index) (Sweeney and Soutar, 2001). Similarly, Table 4 shows that the 9-factor model is the best-fit for the independent variables, with the lowest $\chi 2 / \mathrm{df}$ and RMSEA and the highest CFI and GFI (Sweeney and Soutar, 2001) (Figure 3).

\begin{tabular}{|l|c|c|c|}
\hline \multicolumn{1}{|c|}{ Fit indices } & Criteria & $\begin{array}{c}\text { Dependent CFA } \\
\text { (fit indices) }\end{array}$ & $\begin{array}{c}\text { Independent CFA } \\
\text { (fit indices) }\end{array}$ \\
\hline$\chi \mathbf{2} / \mathbf{d f}$ & $<3$ & 2.66 & 2.30 \\
\hline AGFI & $>0.80$ & 0.94 & 0.89 \\
\hline CFI & $>0.90$ & 0.95 & 0.91 \\
\hline GFI & $>0.90$ & 0.96 & 0.91 \\
\hline RMSEA & $<0.05$ & 0.05 & 0.05 \\
\hline
\end{tabular}

Table 2: Model Fit Statistics

\begin{tabular}{|l|c|c|c|c|c|}
\hline & $\chi$ 2/df & AGFI & CFI & GFI & RMSEA \\
\hline 4-factor model & 2.658 & 0.940 & 0.950 & 0.961 & 0.052 \\
\hline 3-factor model (a) & 5.403 & 0.87 & 0.86 & 0.908 & 0.085 \\
\hline 2-factor model (b) & 8.373 & 0.804 & 0.76 & 0.86 & 0.110 \\
\hline 1-factor model (c) & 12.14 & 0.73 & 0.64 & 0.80 & 0.135 \\
\hline
\end{tabular}

(a) Intention to Search (IS) + Intention to Redeem (IR),

(b) bIS+IR+ Coupon Proneness (CP),

(c) All items in one factor

Table 3: Comparative analysis for Dependent Factors (1st stage data collection) 


\begin{tabular}{|l|c|c|c|c|c|}
\hline & $\chi \mathbf{2} / \mathbf{d f}$ & AGFI & CFI & GFI & RMSEA \\
\hline 9-factor model & 2.304 & 0.885 & 0.906 & 0.907 & 0.046 \\
\hline 8-factor model (a) & 3.855 & 0.795 & 0.789 & 0.831 & 0.069 \\
\hline 7-factor model (b) & 4.127 & 0.768 & 0.766 & 0.805 & 0.072 \\
\hline 6-factor model (c) & 4.248 & 0.768 & 0.753 & 0.802 & 0.073 \\
\hline 5-factor model (d) & 4.764 & 0.742 & 0.711 & 0.778 & 0.079 \\
\hline 4-factor model (e) & 5.492 & 0.699 & 0.652 & 0.739 & 0.086 \\
\hline 3-Factor model (f) & 5.803 & 0.689 & 0.626 & 0.729 & 0.089 \\
\hline 2-factor model (g) & 6.529 & 0.646 & 0.567 & 0.689 & 0.095 \\
\hline 1-factor model (h) & 6.89 & 0.633 & 0.538 & 0.677 & 0.098 \\
\hline
\end{tabular}

(a) Attitude toward Coupon (AC)+ Subjective Norms(SN),

(b) $\mathrm{AC}+\mathrm{SN}+$ Perceived Convenience (PC),

(c) $\mathrm{AC}+\mathrm{SN}+\mathrm{PC}+$ Personal Innovativeness (PI),

(d) $\mathrm{AC}+\mathrm{SN}+\mathrm{PC}+\mathrm{PI}+$ Attitude toward Internet Searching (AIS),

(e) $\mathrm{AC}+\mathrm{SN}+\mathrm{PC}+\mathrm{PI}+\mathrm{AIS}+$ Perceived Risk (PR),

(f) $\mathrm{AC}+\mathrm{SN}+\mathrm{PC}+\mathrm{PI}+\mathrm{AIS}+\mathrm{PR}+$ Face Value $(\mathrm{FV})$,

(g) $\mathrm{AC}+\mathrm{SN}+\mathrm{PC}+\mathrm{PI}+\mathrm{AIS}+\mathrm{PR}+\mathrm{FV}+$ Distance,

(h) All items in one factor

Table 4: Comparative analysis for Independent Factors (1st stage data collection)

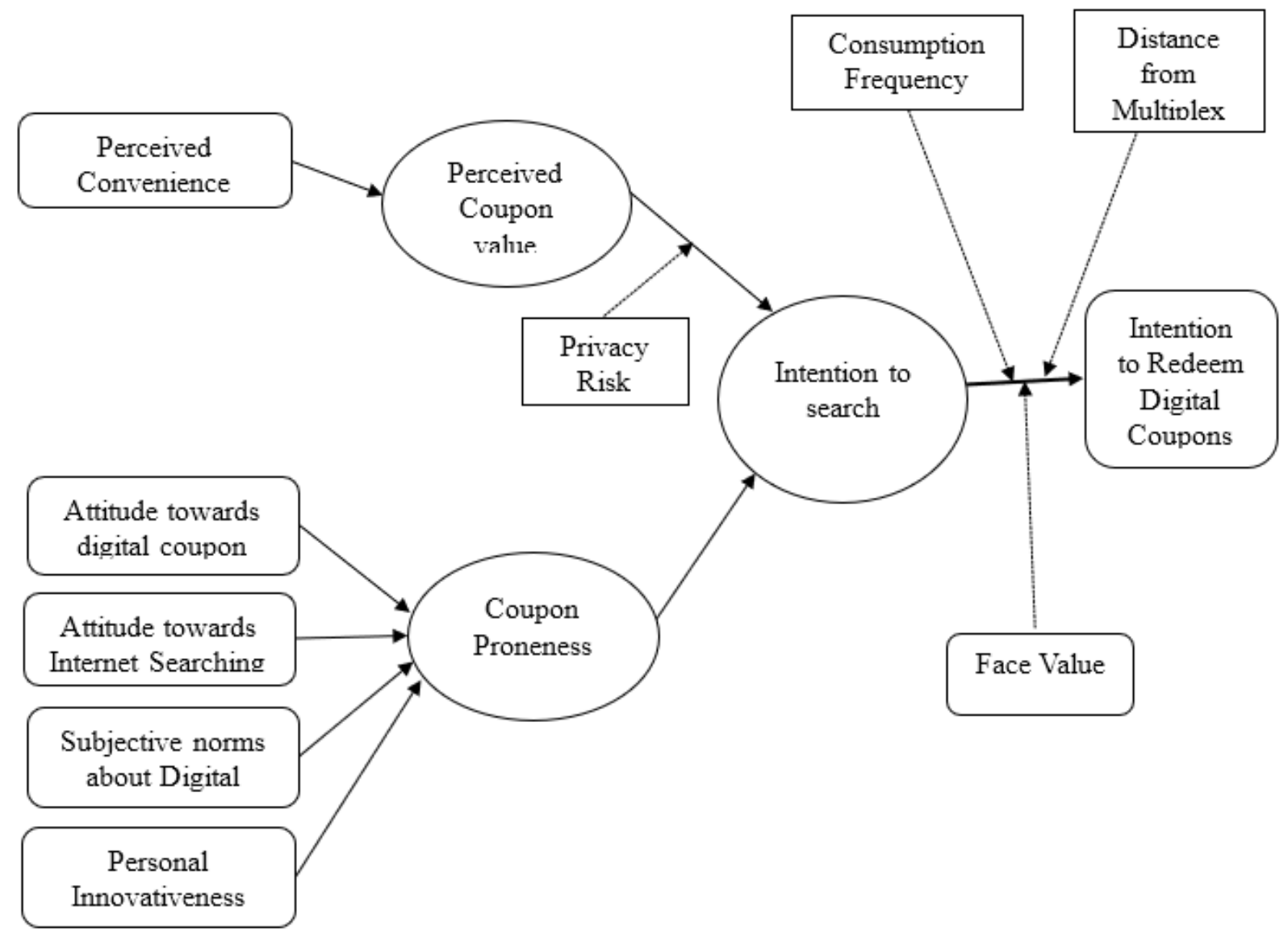

Figure 3: Final Framework after Scale Purification 


\subsection{Convergent and Discriminant Validity}

A validity analysis was conducted after developing the measurement model with dependent and independent factors. Convergent validity is calculated by checking whether the maximum likelihood loading of each item is significant to its underlying factors (Peter, 1981; Arnold and Reynolds, 2003). For all the scale items of dependent and independent factors, factor loading exceeded the minimum threshold value of 0.50 (Tanwar and Prasad, 2017). The dependent and independent factors had a CR value above 0.70 and an AVE above 0.50, indicating good convergent validity (Fornell and Larcker, 1981) (Table 5).

Discriminant validity was calculated by comparing the shared variance between factors with the AVE value of individual factors (Fornell and Larcker, 1981). Discriminant validity is acceptable if the maximum shared variance is less than AVE (MSV $<$ AVE), and the average shared variance is less than AVE (ASV<AVE).

\begin{tabular}{|l|c|c|c|c|}
\hline \multicolumn{1}{|c|}{ Factors } & CR & AVE & MSV & ASV \\
\hline Intention to Redeem Digital Coupons & 0.88 & 0.66 & 0.40 & 0.25 \\
\hline Perceived Coupon Value & 0.85 & 0.66 & 0.40 & 0.25 \\
\hline Coupon Proneness & 0.86 & 0.68 & 0.28 & 0.22 \\
\hline Intention to Search & 0.83 & 0.62 & 0.24 & 0.17 \\
\hline Attitude towards Coupon & 0.84 & 0.65 & 0.59 & 0.26 \\
\hline Subjective Norms & 0.87 & 0.63 & 0.23 & 0.13 \\
\hline Consumption Frequency & 0.72 & 0.50 & 0.46 & 0.23 \\
\hline Distance from Multiplex & 0.80 & 0.50 & 0.31 & 0.18 \\
\hline Attitude towards Internet Searching & 0.80 & 0.51 & 0.37 & 0.18 \\
\hline Perceived Risk & 0.78 & 0.53 & 0.26 & 0.073 \\
\hline Face Value & 0.69 & 0.54 & 0.43 & 0.22 \\
\hline Personal Innovativeness & 0.76 & 0.51 & 0.49 & 0.25 \\
\hline Perceived Convenience & 0.77 & 0.54 & 0.53 & 0.26 \\
\hline
\end{tabular}

Table 5: Validity Statistics for 1st stage data collection

\section{Validation (2nd stage data collection)}

We replicated the CFA on an independent sample to minimize the probability of any error (MacCallum et al., 1992) and validate the model.

\subsection{Replication of CFA}

Professionals from different industries, such as manufacturing, defence, hospitality, IT, and banking, were asked to complete a survey comprising 45 items that accounted for the 13 factors obtained after the first stage of scale purification. A total of 416 completed surveys were received, and because 5 were unusable, we had a final sample of 411 surveys. CFA was replicated in order to validate the scale on a new independent sample for dependent and independent variables separately. The results of the CFA showed a good fit (Table 6). the lowest $\chi 2 / \mathrm{df}$ and RMSEA and the highest CFI and GFI (Sweeney and Soutar, 2001). 


\begin{tabular}{|l|c|c|c|}
\hline \multicolumn{1}{|c|}{ Fit indices } & Criteria & $\begin{array}{c}\text { Dependent } \\
\text { CFA } \\
\text { (fit indices) }\end{array}$ & $\begin{array}{c}\text { Independent } \\
\text { CFA } \\
\text { (fit indices) }\end{array}$ \\
\hline$\chi \mathbf{2} / \mathbf{d f}$ & $<3$ & 2.106 & 2.011 \\
\hline AGFI & $>0.80$ & 0.907 & 0.816 \\
\hline CFI & $>0.90$ & 0.965 & 0.918 \\
\hline GFI & $>0.90$ & 0.942 & 0.852 \\
\hline RMSEA & $<0.05$ & 0.060 & 0.057 \\
\hline
\end{tabular}

Table 6: Model Fit Statistics (2nd stage data collection)

\begin{tabular}{|l|c|c|c|c|c|}
\hline & $\chi \mathbf{2} / \mathbf{d f}$ & AGFI & CFI & GFI & RMSEA \\
\hline 4-factor model & 3.143 & 0.933 & 0.963 & 0.957 & 0.058 \\
\hline 3-factor model (a) & 4.712 & 0.899 & 0.933 & 0.931 & 0.076 \\
\hline 2-factor model (b) & 10.548 & 0.756 & 0.822 & 0.828 & 0.122 \\
\hline 1-factor model (c) & 13.558 & 0.695 & 0.762 & 0.782 & 0.140 \\
\hline
\end{tabular}

(a) Intention to Redeem (IR) + Perceived Coupon Value (PCV),

(b) IR+PCV+ Coupon Proneness (CP),

(c) $\mathrm{IR}+\mathrm{PCV}+\mathrm{CP}+$ Intention to Search

Table 7: Comparative analysis for Dependent Factors (2nd stage data collection)

\begin{tabular}{|l|l|l|l|l|c|}
\hline & $\chi$ 2/df & AGFI & CFI & GFI & RMSEA \\
\hline 9-factor model & 2.601 & 0.873 & 0.931 & 0.897 & 0.050 \\
\hline 8-factor model (a) & 4.646 & 0.758 & 0.839 & 0.800 & 0.076 \\
\hline 7-factor model (b) & 4.911 & 0.726 & 0.824 & 0.770 & 0.078 \\
\hline 6-factor model (c) & 5.252 & 0.720 & 0.806 & 0.762 & 0.082 \\
\hline 5-factor model (d) & 6.092 & 0.682 & 0.766 & 0.726 & 0.089 \\
\hline 4-factor model (e) & 6.994 & 0.629 & 0.722 & 0.678 & 0.097 \\
\hline 3-Factor model (f) & 7.397 & 0.620 & 0.701 & 0.668 & 0.100 \\
\hline 2-factor model (g) & 8.073 & 0.581 & 0.668 & 0.633 & 0.105 \\
\hline 1-factor model (h) & 8.581 & 0.568 & 0.643 & 0.620 & 0.109 \\
\hline
\end{tabular}

(a) Attitude towards coupon (AS)+ Subjective norms (SN),

(b) AS+SN+Perceived convenience (PC),

(c) AS+SN+PC+Personal Innovativeness (PI),

(d) AS+SN+PC+PI+Attitude toward Internet Searching (AIS),

(e) AS+SN+PC+PI+AIS+Perceived Risk (PR),

(f) $\mathrm{AS}+\mathrm{SN}+\mathrm{PC}+\mathrm{PI}+\mathrm{AIS}+\mathrm{PR}+\mathrm{Face}$ value $(\mathrm{FV})$,

(g) $\mathrm{AS}+\mathrm{SN}+\mathrm{PC}+\mathrm{PI}+\mathrm{AIS}+\mathrm{PR}+\mathrm{FV}+$ Distance,

(h) $\mathrm{AS}+\mathrm{SN}+\mathrm{PC}+\mathrm{PI}+\mathrm{AIS}+\mathrm{PR}+\mathrm{FV}+$ Distance+Consumption Frequency.

Table 8: Comparative analysis for Independent Factors (2nd stage data collection)

Further, we compared the proposed 4-factor and 9-factor models with other models. Table 7 and Table 8 show that that the 4 -factor model and the 9-factor model showed the best fit, with the lowest $\chi 2 / \mathrm{df}$ and RMSEA and the highest CFI and GFI (Sweeney and Soutar, 2001) (see Online Appendix). 


\subsection{Convergent and discriminant validity}

In order to assess the validity of the process followed to develop the scale, the purification step was repeated. Factor loading for all the items exceeded 0.50(Hair et al., 2006; Fornell and Larcker, 1981). Further, the CR and AVE values were above 0.70 and above 0.50 , respectively, for all the factors (Fornell and Larcker, 1981). The discriminant validity of the factors was confirmed as the maximum shared variance (MSV $<$ AVE) and the average shared variance were both less than AVE (ASV<AVE) (Table 9).

\begin{tabular}{|l|c|c|c|c|}
\hline \multicolumn{1}{|c|}{ Factors } & CR & AVE & MSV & ASV \\
\hline Intention to Redeem & 0.84 & 0.56 & 0.49 & 0.48 \\
\hline Perceived Coupon Value & 0.70 & 0.54 & 0.38 & 0.40 \\
\hline Coupon Proneness & 0.79 & 0.56 & 0.51 & 0.47 \\
\hline Intention to Search & 0.78 & 0.54 & 0.37 & 0.32 \\
\hline Attitude towards Coupon & 0.85 & 0.65 & 0.44 & 0.32 \\
\hline Subjective Norms & 0.86 & 0.60 & 0.55 & 0.29 \\
\hline Consumption Frequency & 0.85 & 0.59 & 0.44 & 0.38 \\
\hline Distance & 0.83 & 0.62 & 0.55 & 0.35 \\
\hline Attitude towards Internet Searching & 0.80 & 0.52 & 0.50 & 0.28 \\
\hline Perceived Risk & 0.79 & 0.54 & 0.33 & 0.11 \\
\hline Face Value & 0.73 & 0.51 & 0.44 & 0.38 \\
\hline Personal Innovativeness & 0.75 & 0.50 & 0.49 & 0.24 \\
\hline Perceived Convenience & 0.85 & 0.58 & 0.42 & 0.45 \\
\hline
\end{tabular}

Table 9: Validity Statistics

\section{Discussion and Conclusions}

This study presents the first measurement instrument for digital coupon redemption using the rigorous procedure of scale development. Results from two surveys and tests for construct, convergent, and discriminant validity confirmed the robustness of the developed scale. The proposed scale consists of 45 items that measure 13 factors (intention to redeem, intention to search, perceived coupon value, coupon proneness, attitude toward coupons, subjective norms, consumption frequency, distance, attitude toward internet searching, perceived risk, face value, personal innovativeness, and perceived convenience).

The developed scale lends support to the findings of previous studies on coupon redemption. For instance, Chen and $\mathrm{Lu}$ (2011) showed that coupon proneness, attitude toward coupons, attitude toward internet searching, and subjective norms are crucial factors influencing users' intention to redeem digital coupons. Danaher et al. (2015) showed that face value, distance, and perceived convenience were factors affecting redemption. Liu et al. (2015) found that perceive value, coupon proneness, and personal innovativeness positively influence the intention to redeem digital coupons whereas perceived risk negatively influences it. In addition to above factors, the present study considers important new variables such as intention to search and consumption frequency, which also play a role in coupon redemption. By operationalizing the intention to redeem digital coupons, the present study makes a novel contribution to coupon literature. 


\subsection{Implications for Theory}

The proposed scale captures a variety of variables relevant to the redemption of digital coupons. It contributes to marketing literature by drawing attention to coupon redemptiona construct that has the potential to increase sales, enhance brand value, and attract new customers but has not been operationalized till date. Second, this study introduces a new variable-intention to search. This provides new link between: (1) intention to redeem coupons and coupon proneness and (2) intention to redeem coupons and perceived coupon value. These new theoretical linkages offer a fresh perspective on digital coupon redemption. Third, in line with previous literature, the scale confirms that both hedonic benefits (coupon proneness) and utilitarian benefits (perceived coupon value) (Sweeney and Soutar, 2001) influence the consumer's decision to redeem coupons (Clark et al., 2013). Fourth, the proposed scale demonstrates that consumers redeem digital coupons more for hedonic benefits (coupon proneness- subjective norms, innovativeness, and attitude toward internet and coupons) than utilitarian benefits (perceived coupon value- perceived convenience). The reason could be digital coupons are accessed online and it is more fun activity for the consumers than just the money-saving activity. Danaher et al. (2015) found that the redemption rate of digital coupons increases if they are delivered at the right time and place. Fifth, in addition to factors that positively influence digital redemption, this is the first scale on coupons that includes two negative variables: perceived risk and distance. Previous studies argued that one cannot explain digital coupon redemption by considering only the positive variables as technological advancements also come with certain costs. This study has considered perceived risk as negative variables, thereby filling the gap in the literature (Im and Ha, 2015). Finally, the study also raises the following questions, which can be addressed by future researchers:

- Hedonic and utilitarian benefits are crucial for coupon redemption. Are both of them equally important, or is one of them more important than other?

- How can the scale be used by the services and manufacturing industries?

- Does consumer perception about redemption vary across different product categories?

- $\quad$ Are the factors relevant to the redemption of traditional coupons different from those for digital coupons?

- Which positive or negative factors play a dominant role in coupon redemption?

\subsection{Implications for Practice}

Our findings can help strengthen the strategies used to increase digital coupon redemption. First, the scale can be used by marketers to gain insights into the factors that influence coupon redemption. Second, intention to search for digital coupon can be enhanced by making navigation of the coupon website as an enjoyable and fun activity. Therefore, marketers should make the website interesting by introducing various innovative features. Third, the redemption experience can be made enjoyable through innovative messages and emojis. Emarketers should ensure that coupon redemption is a hassle-free experience. The marketers can also work on end to end coupon redemption journey. The marketers should explore the methods to make it seamless and convenient thus reducing the customer efforts in redemption leading to customer delight. Moreover, consumer preferences such as preferred time and place (Danaher et al., 2015) should be incorporated into coupon campaigns to make the redemption process more convenient. Fourth, coupon redemption may increase if e-marketers invest 
efforts in making the journey of coupon redemption more exciting instead of focusing only on offering discounts (Ieva et al., 2018).

Fifth, e-marketers can deliver coupons to consumers who purchase products more frequently as their chances of redemption may be higher. Sixth, e-marketers should not waste their promotional budget on consumers who live far from the coupon redemption location as long distances are negatively correlated with redemption intention. Lastly, to mitigate the perceived risk factors in an online environment, e-marketers should design websites and policies that address consumers' privacy, security, and other concerns (Pandey and Gudipudi, 2019). Customized coupons delivered at schedule times (Mantel and Kellaris, 2003) are known to reduce the fear of spam among consumers (Mogilner and Aaker, 2009). Moreover, marketers can track consumer browsing history with analytics and send the coupons accordingly. It will also reduce the spams in the consumer's inbox.

\subsection{Avenues for Further Research}

The reliable and valid scale for coupon redemption presented here is not without limitations. In fact, it serves as a good starting point for researchers and practitioners to conduct more insightful investigations into the redemption phenomenon. One of the main limitations of the data collected for scale development is that it is cross-sectional in nature, and it measures intention rather than actual behaviour. In future, researchers can collect longitudinal data from consumers who use digital coupons to refine the scale and observe how users' redemption intention evolves with changes in technology and experience. It would also be interesting to develop a scale that is based on actual redemption behaviours of the consumers. Finally, this scale is based on data obtained from consumers in an emerging market. Given that user behaviour changes with context, it may be useful to replicate the scale development process with consumers in a developed country.

\section{References}

Agarwal, R., \& Prasad, J. (1998). A conceptual and operational definition of personal innovativeness in the domain of information technology. Information Systems Research, 9(2), 204-215.

Ajzen, I. (1985). From intentions to actions: A theory of planned behavior. In Action Control (pp. 11-39). Springer, Berlin, Heidelberg.

Arnold, M. J., \& Reynolds, K. E. (2003). Hedonic shopping motivations. Journal Of Retailing, 79(2), 77-95.

Bagozzi, R. P., Baumgartner, H., \& Yi, Y. (1992). Appraisal processes in the enactment of intentions to use coupons. Psychology \& Marketing, 9(6), 469-486.

Banerjee, S., \& Yancey, S. (2010). Enhancing mobile coupon redemption in fast food campaigns. Journal of Research in Interactive Marketing.

Beeck, I., \& Toporowski, W. (2017). When location and content matter: effects of mobile messages on intention to redeem. International Journal of Retail $\mathcal{E}$ Distribution Management, 45(7/8), 826-843.

Bowman, R. D. (1980). Couponing and rebates: Profit on the dotted line. Lebhar-Friedman Books.

Chen, M. F., \& Lu, T. Y. (2011). Modeling e-coupon proneness as a mediator in the extended TPB model to predict consumers' usage intentions. Internet Research, 21(5), 508-526. 
Chi, T., \& Kilduff, P. P. (2011). Understanding consumer perceived value of casual sportswear: An empirical study. Journal of Retailing and Consumer Services, 18(5), 422-429.

Chiou-Wei, S. Z. (2004). The determinants of direct mail coupon usage revisited: Evidence from count panel data models. Agribusiness: An International Journal, 20(2), 189-200.

Chiou-Wei, S. Z., \& Inman, J. J. (2008). Do shoppers like electronic coupons?: A panel data analysis. Journal of Retailing, 84(3), 297-307.

Churchill Jr, G. A. (1979). A paradigm for developing better measures of marketing constructs. Journal of marketing research, 16(1), 64-73.

Clark, R. A., Zboja, J. J., \& Goldsmith, R. E. (2013). Antecedents of coupon proneness: a key mediator of coupon redemption. Journal of Promotion Management, 19(2), 188-210.

Colwell, S. R., Aung, M., Kanetkar, V., \& Holden, A. L. (2008). Toward a measure of service convenience: multiple-item scale development and empirical test. Journal of Services Marketing, 22(2), 160-169.

Corbin, J. M., \& Strauss, A. (1990). Grounded theory research: Procedures, canons, and evaluative criteria. Qualitative Sociology, 13(1), 3-21.

Danaher, P. J., Smith, M. S., Ranasinghe, K., \& Danaher, T. S. (2015). Where, when, and how long: Factors that influence the redemption of mobile phone coupons. Journal of Marketing Research, 52(5), 710-725.

Dang, D., Pittayachawan, S., \& Nkhoma, M. (2015). Demystifying online personas of Vietnamese young adults on Facebook: A Q-methodology approach. Australasian Journal of Information Systems, 19, 1-22.

Dickinger, A., \& Kleijnen, M. (2008). Coupons going wireless: Determinants of consumer intentions to redeem mobile coupons. Journal of Interactive Marketing, 22(3), 23-39.

Featherman, M. S., Miyazaki, A. D., \& Sprott, D. E. (2010). Reducing online privacy risk to facilitate e-service adoption: the influence of perceived ease of use and corporate credibility. Journal of Services Marketing, 24(3), 219-229.

Fornell, C., \& Larcker, D. F. (1981). Evaluating structural equation models with unobservable variables and measurement error. Journal of Marketing Research, 18(1), 39-50.

Fortin, D. R. (2000). Clipping coupons in cyberspace: A proposed model of behavior for dealprone consumers. Psychology \& Marketing, 17(6), 515-534.

Garretson, J. A., \& Burton, S. (2003). Highly coupon and sale prone consumers: benefits beyond price savings. Journal of Advertising Research, 43(2), 162-172.

Ha, Y., \& Im, H. (2014). Determinants of mobile coupon service adoption: assessment of gender difference. International Journal of Retail \& Distribution Management, 42(5), 441-459.

Hair, J. F., Black, W. C., Babin, B. J., Anderson, R. E. \& Tatham, R. L. (2006): Multivariate Data Analysis. Auflage, Upper Saddle River, NJ.

Hinkin, T. R. (1995). A review of scale development practices in the study of organizations. Journal of Management, 21(5), 967-988.

Honea, H., \& Dahl, D. W. (2005). The promotion affect scale: defining the affective dimensions of promotion. Journal of Business Research, 58(4), 543-551. 
Hsu, M. H., Chang, C. M., Chu, K. K., \& Lee, Y. J. (2014). Determinants of repurchase intention in online group-buying: The perspectives of DeLone \& McLean IS success model and trust. Computers in Human Behavior, 36, 234-245.

Huang, H. C., Chang, Y. T., Yeh, C. Y., \& Liao, C. W. (2014). Promote the price promotion: The effects of price promotions on customer evaluations in coffee chain stores. International Journal of Contemporary Hospitality Management, 26(7), 1065-1082.

Ieva, M., De Canio, F., \& Ziliani, C. (2018). Daily deal shoppers: What drives social couponing?. Journal of Retailing and Consumer Services, 40, 299-303.

Im, H., \& Ha, Y. (2012). Who are the users of mobile coupons? A profile of US consumers. Journal of Research in Interactive Marketing, 6(3), 215-232.

Im, H., \& Ha, Y. (2013). Enablers and inhibitors of permission-based marketing: A case of mobile coupons. Journal of Retailing and Consumer Services, 20(5), 495-503.

Im, H., \& Ha, Y. (2015). Is this mobile coupon worth my private information? Consumer evaluation of acquisition and transaction utility in a mobile coupon shopping context. Journal of Research in Interactive Marketing, 9(2), 92-109.

Jiménez, F. R., \& Mendoza, N. A. (2013). Too popular to ignore: The influence of online reviews on purchase intentions of search and experience products. Journal of Interactive Marketing, 27(3), 226-235.

Kaiser, H. F., \& Rice, J. (1974). Little jiffy, mark IV. Educational and Psychological Measurement, 34(1), 111-117.

Kang, H., Hahn, M., Fortin, D. R., Hyun, Y. J., \& Eom, Y. (2006). Effects of perceived behavioral control on the consumer usage intention of e-coupons. Psychology $\mathcal{E}$ Marketing, 23(10), 841-864.

Khajehzadeh, S., Oppewal, H., \& Tojib, D. (2015). Mobile coupons: what to offer, to whom, and where?. European Journal of Marketing, 49(5/6), 851-873.

Kumar, R., Sachan, A., \& Kumar, R. (2020). The Impact of Service Delivery System Process and Moderating Effect of Perceived Value in Internet Banking Adoption. Australasian Journal of Information Systems, 24.

Lichtenstein, D. R., Netemeyer, R. G., \& Burton, S. (1990). Distinguishing coupon proneness from value consciousness: An acquisition-transaction utility theory perspective. Journal of Marketing, 54(3), 54-67.

Lindell, M. K., \& Whitney, D. J. (2001). Accounting for common method variance in crosssectional research designs. Journal of Applied Psychology, 86(1), 114.

Liu, F., Zhao, X., Chau, P. Y., \& Tang, Q. (2015). Roles of perceived value and individual differences in the acceptance of mobile coupon applications. Internet Research, 25(3), 471495.

MacCallum, R. C., Roznowski, M., \& Necowitz, L. B. (1992). Model modifications in covariance structure analysis: the problem of capitalization on chance. Psychological Bulletin, 111(3), 490. 
Madlberger, M., \& Matook, S. (2017). Theorizing E-Commerce business models: On the impact of partially and fully supported transaction phases on customer satisfaction and loyalty. Australasian Journal Of Information Systems, 21.

Mantel, S. P., \& Kellaris, J. J. (2003). Cognitive determinants of consumers' time perceptions: The impact of resources required and available. Journal of Consumer Research, 29(4), 531538.

Mills, P., \& Zamudio, C. (2018). Scanning for discounts: examining the redemption of competing mobile coupons. Journal of the Academy of Marketing Science, 46(5), 964-982.

Mogilner, C., \& Aaker, J. (2009). "The time vs. money effect": Shifting product attitudes and decisions through personal connection. Journal of Consumer Research, 36(2), 277-291.

Murphy, C., Klotz, A. C., \& Kreiner, G. E. (2017). Blue skies and black boxes: The promise (and practice) of grounded theory in human resource management research. Human Resource Management Review, 27(2), 291-305.

Nahm, A. Y., Vonderembse, M. A., \& Koufteros, X. A. (2004). The impact of organizational culture on time-based manufacturing and performance. Decision Sciences, 35(4), 579-607.

Nayal, P., \& Pandey, N. (2020). Redemption Intention of Coupons: A Meta-Analytical Review and Future Directions. Journal of Promotion Management, 1-24.

NCH Report 2018, https://www.nchmarketing.com/2018-Year-End-Coupon-Facts-At-AGlance.aspx accessed on May 1, 2019

Netemeyer, R. G., Bearden, W. O., \& Sharma, S. (2003). Scaling procedures: Issues and applications. Sage Publications.

Nunnally, J., \& Bernstein, I. (1994). Psychometric Theory. New York, NY: McGraw-Hall.

Pandey, N., \& Gudipudi, B. (2019). Understanding 'what is privacy for millennials on Facebook in India. Journal of Data Protection \& Privacy, 2(3), 224-233.

Pandey, N., \& Maheshwari, V. (2017). Four decades of coupon research in pricing: Evolution, development, and practice. Journal of Revenue and Pricing Management, 16(4), 397-416.

Pandey, N., \& Singh, G. (2012). Marketing issues in SMEs: Cases from India. Pearson Education India.

Papadas, K. K., Avlonitis, G. J., \& Carrigan, M. (2017). Green marketing orientation: Conceptualization, scale development and validation. Journal of Business Research, 80, 236-246.

Parasuraman, A., Zeithaml, V. A., \& Berry, L. L. (1988). Servqual: A multiple-item scale for measuring consumer perc. Journal of Retailing, 64(1), 12.

Patwardhan, A. A., Pandey, N., \& Dhume, S. M. (2017). Integrated model for understanding Indian physicians' internet usage pattern: An empirical approach. International Journal of Healthcare Management, 10(1), 19-33.

Patyal, V. S., \& Koilakuntla, M. (2015). Infrastructure and core quality practices in Indian manufacturing organizations: Scale development and validation. Journal of Advances in Management Research, 12(2), 141-175. 
Peter, J. P. (1981). Construct validity: A review of basic issues and marketing practices. Journal of Marketing Research, 18(2), 133-145.

Podsakoff, P. M., MacKenzie, S. B., Lee, J. Y., \& Podsakoff, N. P. (2003). Common method biases in behavioral research: A critical review of the literature and recommended remedies. Journal of Applied Psychology, 88(5), 879.

Pura, M. (2005). Linking perceived value and loyalty in location-based mobile services. Managing Service Quality, 15(6), 509-538.

Raghubir, P. (2004). Coupons in context: discounting prices or decreasing profits? Journal of Retailing, 80(1), 1-12.

Reichhart, P., Pescher, C., \& Spann, M. (2013). A comparison of the effectiveness of e-mail coupons and mobile text message coupons for digital products. Electronic Markets, 23(3), 217-225.

Rhee, H., \& Bell, D. R. (2002). The inter-store mobility of supermarket shoppers. Journal of Retailing, 78(4), 225-237.

Shimp, T. A., \& Kavas, A. (1984). The theory of reasoned action applied to coupon usage. Journal of Consumer Research, 11(3), 795-809.

Sieger, P., Gruber, M., Fauchart, E., \& Zellweger, T. (2016). Measuring the social identity of entrepreneurs: Scale development and international validation. Journal of Business Venturing, 31(5), 542-572.

Souiden, N., Chaouali, W., \& Baccouche, M. (2019). Consumers' attitude and adoption of location-based coupons: The case of the retail fast food sector. Journal of Retailing and Consumer Services, 47, 116-132.

Swaminathan, S., \& Bawa, K. (2005). Category-specific coupon proneness: The impact of individual characteristics and category-specific variables. Journal of Retailing, 81(3), 205214.

Sweeney, J. C., \& Soutar, G. N. (2001). Consumer perceived value: The development of a multiple item scale. Journal of Retailing, 77(2), 203-220.

Tanwar, K., \& Prasad, A. (2017). Employer brand scale development and validation: a secondorder factor approach. Personnel Review, 46(2), 389-409.

To, P. L., Liao, C., \& Lin, T. H. (2007). Shopping motivations on Internet: A study based on utilitarian and hedonic value. Technovation, 27(12), 774-787.

Wierich, R., \& Zielke, S. (2014). How retailer coupons increase attitudinal loyalty-the impact of three coupon design elements. European Journal of Marketing, 48(3/4), 699-721.

Copyright: @ 2020 Nayal \& Pandey. This is an open-access article distributed under the terms of the Creative Commons Attribution-NonCommercial 3.0 Australia License, which permits non-commercial use, distribution, and reproduction in any medium, provided the original author and AJIS are credited. 


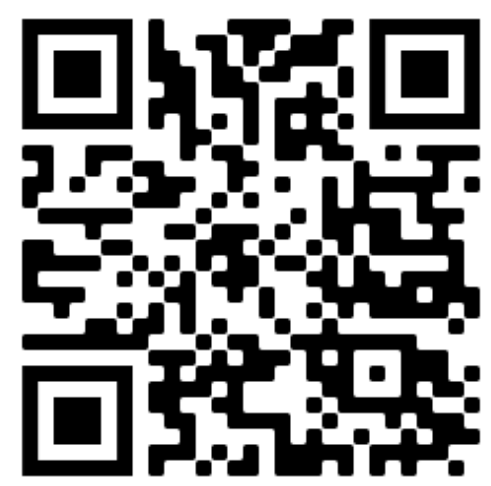

